\title{
Stroke-prevenció időskorban: az edoxabán hatékonysága és biztonságossága idős betegekben az ENGAGE AF vizsgálat eredményei alapján
}

\author{
Márk László dr. \\ Békés Megyei Központi Kórház, Pándy Kálmán Tagkórház, II. Belgyógyászat-Kardiológia, Gyula
}

\begin{abstract}
A pitvarfibrilláció a leggyakoribb klinikai jelentőséggel bíró ritmuszavar. Gyakran okoz szisztémás thromboemboliás eseményeket, melyek megelőzésére hagyományosan évtizedekig a K-vitamin-antagonista gyógyszereket alkalmaztuk. Az új, direkt antikoagulánsok megjelenése forradalmi újítást jelentett a kezelésben, ezek fokozatos térhódítása, nagymértékű elterjedése várható. A Magyarországon legújabban forgalomba hozott edoxabán a Xa-faktort gátolja. Nagy előnye a napi egyszeri szedés és a kedvező biztonságossági profil. Nagy betegszámú klinikai vizsgálat azt igazolta, hogy a stroke és a szisztémás emboliák megelőzésében legalább annyira hatékony, mint a warfarin, ugyanakkor az okozott súlyos vérzések száma szignifikánsan kevesebb volt. Mivel a pitvarfibrilláció gyakorisága az életkorral fokozatosan emelkedik, nagy jelentősége lehet annak a megfigyelésnek, hogy a többi direkt orális antikoagulánssal összehasonlítva idősebb korban a nettó klinikai előny (a megelőzött thromboemboliás események és az okozott vérzéses szövődmények aránya) az edoxabán esetében kedvező.
\end{abstract}

Orv Hetil. 2018; 159(20): 798-802.

Kulcsszavak: nem K-vitamin-antagonista orális antikoanguláns, direkt orális antikoaguláns, warfarin, edoxabán, időskor

\section{Stroke prevention in the elderly: effectiveness and safety of edoxaban in elderly patients according to the results of the ENGAGE AF study}

\begin{abstract}
Atrial fibrillation is the most common clinically relevant arrhythmia frequently causing systemic thromboembolic events. Traditionally vitamin $\mathrm{K}$ antagonists had been used for decades to prevent these events. The emerging of the new direct anticoagulants has revolutionized this treatment and a gradual growth and extensive spread of usage is expected. The latest one approved in Hungary, edoxaban, is a factor Xa inhibitor. Once-daily administration and favourable safety profile are major benefits of this drug. In a large clinical study with a high number of patients it proved to be at least as effective as warfarin in the prevention of stroke and systemic embolization while causing significantly less major bleedings. As the incidence of atrial fibrillation increases with age, the observation that, compared with the other direct oral anticoagulants, the administration of edoxaban in the elderly has a favourable net clinical benefit (in the rate of prevented thromboembolic events and the number of caused bleedings) may have a great importance.
\end{abstract}

Keywords: non-vitamin K antagonist oral anticoagulants, direct oral anticoagulants, warfarin, edoxaban, elderly

Mark L. [Stroke prevention in the elderly: effectiveness and safety of edoxaban in elderly patients according to the results of the ENGAGE AF study]. Orv Hetil. 2018; 159(20): 798-802.

(Beérkezett: 2018. február 27.; elfogadva: 2018. március 14.) 


\section{Rövidítések}

$\mathrm{CHADS}_{2}$ score (Congestive heart failure, Hypertension, Age > 75 years, Diabetes mellitus, Stroke) szívelégtelenség, hypertonia, előrehaladott kor, cukorbetegség, (esetleges) stroke alapján meghatározott rizikópontszám; CI = konfidenciaintervallum; DOAC = direkt orális antikoaguláns; ENGAGE AF-TIMI 48 = Effective aNticoaGulation with factor Xa next GEneration in Atrial Fibrillation-Thrombolysis In Myocardial Infarction study 48; HAS-BLED score $=$ (Hypertension, Abnormal renal/liver function, Stroke, Bleeding history or predisposition, Labile international normalized ratio, Elderly [ $>65$ years] Drugs/alcohol concomitantly) hypertonia, abnormális vese- és májmúködés, stroke, vérzés, labilis nemzetközi normalizált ráta, időskor (65 év felett), gyógyszerszedés vagy alkoholfogyasztás alapján meghatározott rizikópontszám; HR = (hazard ratio) kockázati hányados; $\mathrm{NOAC}=$ (novel oral anticoagulant $)$ új orális antikoaguláns; $\mathrm{PF}=$ pitvarfibrilláció; TTR $=$ (time in the therapeutic range) a terápiás tartományban töltött idő

A pitvarfibrilláció (PF) a leggyakoribb tartósan fennálló ritmuszavar, világszerte hozzávetôlegesen 33,5 millió embert érint, a gyakorisága a fejlett országokban magasabb. Négy európai vagy észak-amerikai középkorú felnőttből egynél várható a kialakulása $[1,2]$. A PF önmagában nőknél a kétszeresére, férfiaknál a másfélszeresére növeli a bármely okból bekövetkező halálozás kockázatát, aminek oka leginkább hirtelen szívhalál, szívelégtelenség és stroke. Az ischaemiás stroke-ok kb. egyötöde függ össze PF-val, ezek általában súlyosabb lefolyásúak, 60\%-uk végleges és jelentős mozgáskorlátozottsággal, 20\%-uk pedig halállal jár [3]. A PF-betegeknél gyakran észlelhetô agyi fehérállomány-károsodás, a kognitív funkció és az életminőség romlása, depressziós hangulat [1].

Orális antikoagulánsok alkalmazásával a stroke-ok kétharmada megelőzhető lenne.

A K-vitamin-antagonistákkal [4-6] és az új típusú szerekkel - amelyeket az orvosi irodalomban 'novel oral anticoagulants' vagy 'non-vitamin $\mathrm{K}$ antagonist oral anticoagulants' (NOAC) vagy direkt orális antikoagulánsok (DOAC) néven egyaránt említenek - végzett kezelés jelentősen csökkenti a stroke kialakulását és a halálozást [7, 8]. Az egyéb beavatkozások, mint a ritmuskontroll vagy a frekvenciakontroll, bár a tüneteket és az életminőséget javíthatják, és segítik a szív pumpafunkciójának megőrzését, hosszú távon nem csökkentik a mortalitást és a morbiditást [1].

A kezelés fontosságának egyre szélesedő elismerése ellenére jól ismert tény, hogy az irányelvek szerint az orális antikoaguláns kezelésre javasolt betegeknek csupán a fele kapja a kezelést [9], és tudott az is, hogy a kezelés mellett stroke-ot elszenvedők 80\%-ánál az nem megfelelő minőségü [10]. A DOAC-ok piaci megjelenése és egyre növekvő elterjedése újra ráirányította a figyelmet a PF-ra, és jelentősen növelte a megfelelően kezelt betegek arányát is. Magyarországon immár négy ilyen szer, a dabigatrán, a rivaroxabán, az apixabán és az edoxabán hoz- záférhető. Ezen szereknél nincsen titrálás, nem szükséges gyakori laborellenőrzés, a terápia fix dózisokkal történik. Vannak olyan helyzetek, mint például a vese csökkent múködése vagy az idős betegek, amikor az adagolásra nagyobb figyelmet kell fordítani. Ez utóbbi betegcsoport különösen érdekes, hiszen az életkorral együtt nemcsak a PF prevalenciája nő meg, hanem a stroke és a vérzésveszély is. A jelen összefoglalóban a magyar piacon a legújabb DOAC, az edoxabán 65 év feletti életkorú betegek esetében történő alkalmazását és hatását elemezzük az Effective aNticoaGulation with factor Xa next GEneration in Atrial Fibrillation-Thrombolysis In Myocardial Infarction study 48 (ENGAGE AF-TIMI 48) tanulmány [11, 12] alcsoporti elemzése alapján [13].

\section{Az ENGAGE AF vizsgálat}

Egy új molekula klinikai vizsgálata során két mérlegelési szempont van: 1) van-e olyan hatékony, mint a korábbi legjobbnak gondolt kezelés; 2) mennyire biztonságos a régi kezeléshez képest. A PF-ban alkalmazott DOAC-ok esetében azok voltak a mérlegelési szempontok, hogy a warfarinhoz képest mennyire tudják megelózni a stroke vagy a szisztémás emboliás események kialakulását, és hogy milyen gyakoriak a vérzéses mellékhatások. A Xafaktort gátló edoxabán ezen vizsgálatát 21105 olyan betegen végezték, akik PF-ja 12 hónapon belül kezdődött, a $\mathrm{CHADS}_{2}$ score 2 vagy magasabb volt. Kettős vakmódszerrel 3 ágra történt randomizáció: warfarin, nagy dózisú kezelés: $60 \mathrm{mg}$ edoxabán és alacsony dózisú kezelés: $30 \mathrm{mg}$ edoxabán. A medián követési idő 2,8 év volt. A késóbbi elemzések egy részében csak a warfarin- és a 60 mg edoxabánkart vették figyelembe, mert a nagy dózisú kezelés $(60 \mathrm{mg} / 30 \mathrm{mg})$ forgalomba hozatalát engedélyezték. Az edoxabán kezelési ágon már az indulástól, a NOAC vizsgálatok közül pedig egyedülállóan, később - a randomizációt követő időben is - dóziscsökkentés történhetett: 30 mg-ot kaptak azok a betegek, akiknek a kreatininclearance-e 30-50 ml/1 között volt, akik $60 \mathrm{~kg}$ vagy annál alacsonyabb testsúlyúak voltak, valamint kinidint, dronedaront vagy verapamilt szedtek. Az életkor nem volt dóziscsökkentési szempont. A későbbiekben az alkalmazási előiratba a kinidin és a verapamil mint alacsonyabb dózist igénylő gyógyszerek szedése nem került bele. A klinikai vizsgálat eredménye után az alkalmazási elóirat alapján a nálunk nem forgalmazott dronedaron mellett a ciklosporin, az eritromicin és a ketokonazol szedésekor javasolt a $30 \mathrm{mg}$, és a kreatininclearance 15 és $50 \mathrm{ml} /$ perc közötti értékénél, valamint a $60 \mathrm{~kg}$ alatti testsúly esetén. A warfarinágon a betegek igen jól voltak kezelve, a többi DOAC hatását vizsgáló tanulmányhoz képest itt volt a legmagasabb a terápiás tartományban eltöltött idő $($ TTR $=68,4 \%)$. Az elsődleges végpont a stroke vagy szisztémás embolisatio gyakorisága volt, mely 13\%-kal kisebbnek bizonyult az edoxabáncsoportban (HR 0,87 [97,5\% CI: 0,73-1,04]). Szignifikánsan csökkent a másodlagos végpontok közül többek között a 
stroke, a szisztémás embolia és a cardiovascularis halál kompozit végpontja ( $\mathrm{HR} 0,87, \mathrm{p}=0,005)$, és a cardiovascularis halálozás $(\mathrm{HR} 0,86, \mathrm{p}=0,013)$. A biztonságossági szempontok között a súlyos vérzés előfordulása volt az elsődleges, ennek gyakorisága 3,43\%/év volt a warfarinágon és 2,75\%/év az edoxabánágon, HR 0,80 (95\% CI 0,71-0,9l), p<0,001. Az edoxabán a különböző vérzések (major, minor, életveszélyes, klinikailag nem releváns minor vérzés) tekintetében szignifikánsan jobb eredményeket hozott. A fatális vérzés (melynek 79\%-a intracerebralis haemorrhagia volt) $0,33 \%$ /év gyakoriságúnak bizonyult a warfarin- és $0,18 \%$ /év gyakoriságúnak az edoxabánágon $(\mathrm{p}=0,003)$. Az egész ENGAGE AF vizsgálat eredményeit tekintve az állapítható meg, hogy a $60 \mathrm{mg}$ edoxabán legalább olyan jó volt a stroke vagy a szisztémás emboliás események megelőzése tekintetében, mint a warfarin, de sokkal kedvezőbb biztonságossági profillal (szignifikánsan kevesebb vérzéses szövődménnyel) [12].

\section{Az edoxabán hatása az ENGAGE AF különböző életkori csoportjaiban}

A PF előfordulása az életkor előrehaladásával jelentősen nő, ez ismert a napi gyakorlatból, és tükröződik az ENGAGE AF-betegeink életkori megoszlásában is $(65$ év alatt 26\%, 65-74 év között 34\%, 75 év és a fölött $40 \%$ ). Ugyanakkor az idősebb betegeinket jobban féltjük a mellékhatásoktól is, emiatt az idősebbekben az antikoaguláns kezelést nehezebben kezdjük el. Érdemes megvizsgálni, hogy ebben a több mint 21 ezer betegen történt vizsgálatban az életkor függvényében milyen volt a stroke és az embolisatio megelőzése, valamint a vérzés gyakorisága. Erről Kato és mtsai 2016 májusában a Journal of the American Heart Association folyoiratban megjelent közleményükben (melynek 6. szerzője Kiss Róbert Gábor) számoltak be. Három életkori csoportot alkalmaztak: 65 év alattiak, 65 és 74 évesek és 75 évesek vagy idősebbek; az 1. táblázat a betegek induláskori adatait mutatja be. Látható, hogy az életkorral csökkent a testsúly és a kreatininclearance átlaga. Időseken nagyobb a HAS-BLED score értéke, gyakoribb a randomizáláskor csökkentett adagúak aránya. A stroke és a szisztémás emboliás esemény a warfarinágon (ami a korábbi kezelésünkben volt az ideális terápia etalonja) a három életkori csoportban növekvő gyakoriságú volt $(1,1 \%, 1,8 \%$ és $2,3 \%)$ ugyanúgy, mint a major vérzés $(1,8 \%, 3,3 \%$ és $4,8 \%$ ) ( $\mathrm{p}$-trend $<0,001$ mindkét esetben). A 75 éves vagy annál idősebb korosztályban a warfarin- és az edoxabáncsoport között nem volt szignifikáns különbség a stroke vagy szisztémás embolia gyakoriságában ( $\mathrm{HR} \quad 0,83$ $[0,66-1,04])$, de az volt az edoxabán javára a major vérzések szempontjából (HR 0,83 [0,70-0,99]). Másképp megfogalmazva, az edoxabán az idősek között mutatott kifejezettebb nettó klinikai előnyt az ENGAGE AF vizsgálatban (1. ábra). Az elemzés tanulsága, hogy a kor előrehaladásának, az öregedésnek nagyobb jelentősége van
1. táblázat | Korcsoport szerinti betegadatok az ENGAGE AF vizsgálatban

\begin{tabular}{|c|c|c|c|}
\hline & $\begin{array}{c}<65 \text { év } \\
(\mathrm{n}=5497)\end{array}$ & $\begin{array}{l}65-74 \text { év } \\
(\mathrm{n}=7134)\end{array}$ & $\begin{array}{c}\geq 75 \text { év } \\
(\mathrm{n}=8474)\end{array}$ \\
\hline Nö (\%) & 27 & 39 & 45 \\
\hline Dyslipidaemia (\%) & 51 & 54 & 52 \\
\hline Warfarin TTR (\%) & 67 & 69 & 70 \\
\hline $\mathrm{CHADS}_{2}$ score (átlag) & 2,6 & 2,7 & 3,2 \\
\hline $\begin{array}{l}\text { Pangásos szívelégtelenség } \\
(\%)\end{array}$ & 70 & 63 & 45 \\
\hline Hypertonia (\%) & 94 & 94 & 93 \\
\hline Átlagkor (év) & 59 & 70 & 79 \\
\hline Diabetes $(\%)$ & 41 & 43 & 28 \\
\hline $\begin{array}{l}\text { Korábbi stroke vagy TIA } \\
(\%)\end{array}$ & 28 & 33 & 25 \\
\hline HAS-BLED score $\geq 3(\%)$ & 16 & 57 & 56 \\
\hline Átlag $\mathrm{CrCl}(\mathrm{ml} / \mathrm{min})$ & 98 & 74 & 56 \\
\hline Átlagtestsúly (kg) & 91 & 83 & 76 \\
\hline $\begin{array}{l}\text { Dóziscsökkentés } \\
\text { randomizációkor (\%) }\end{array}$ & 10 & 18 & 41 \\
\hline
\end{tabular}

a vérzések szempontjából, mint a thromboemboliás események oldaláról. Ebben az edoxabán alkalmazása kedvezőbb hatású volt, idősebbeken jelentősebb abszolút csökkenést eredményezett a biztonsági (vérzés) oldalon [13].

\section{A négy DOAC időskorban kifejtett hatásának összehasonlítása}

A PF gyakorisága az életkorral fokozatosan növekszik, emiatt nagy jelentőségü az okozott thromboemboliás események megelőzése, mert az életkorral együtt nemcsak ezek, hanem a vérzésveszély is növekszik. Idősebb korban gyakoribb a vesemúködési zavar, az ischaemiás szívbetegség előfordulása, az idősebbek több gyógyszert szednek, és általában sérülékenyebbek. A 2. táblázat Turagam és mtsai összefoglalása alapján a négy DOAC hatását tekinti át stroke és szisztémás embolisatio, valamint major vérzés előfordulása szempontjából a 65-74 éves és a 75 éves és annál idősebb betegek körében a szerekkel végzett klinikai vizsgálatok eredményei alapján [14]. Az elemzés megmutatja, hogy a 75 év feletti korcsoportban az edoxabán esetében kifejezett a nettó klinikai előny, ami nem jellemző mindegyik DOAC-ra.

\section{Következtetések}

A DOAC-ok elterjedése megállíthatatlan folyamat, ami teljesen érthetőnek látszik, ha összehasonlítjuk a hatásukat és az előnyeiket a K-vitamin-antagonistákéival. A Magyarországon megjelent új DOAC, az edoxabán igen nagy betegszámon, a több mint 21 ezer résztvevővel végzett ENGAGE AF vizsgálatban igazolta, hogy a szer 
Elsődleges nettó klinikai előny

(Stroke, szisztémás emboliás esemény, halál, major vérzés)

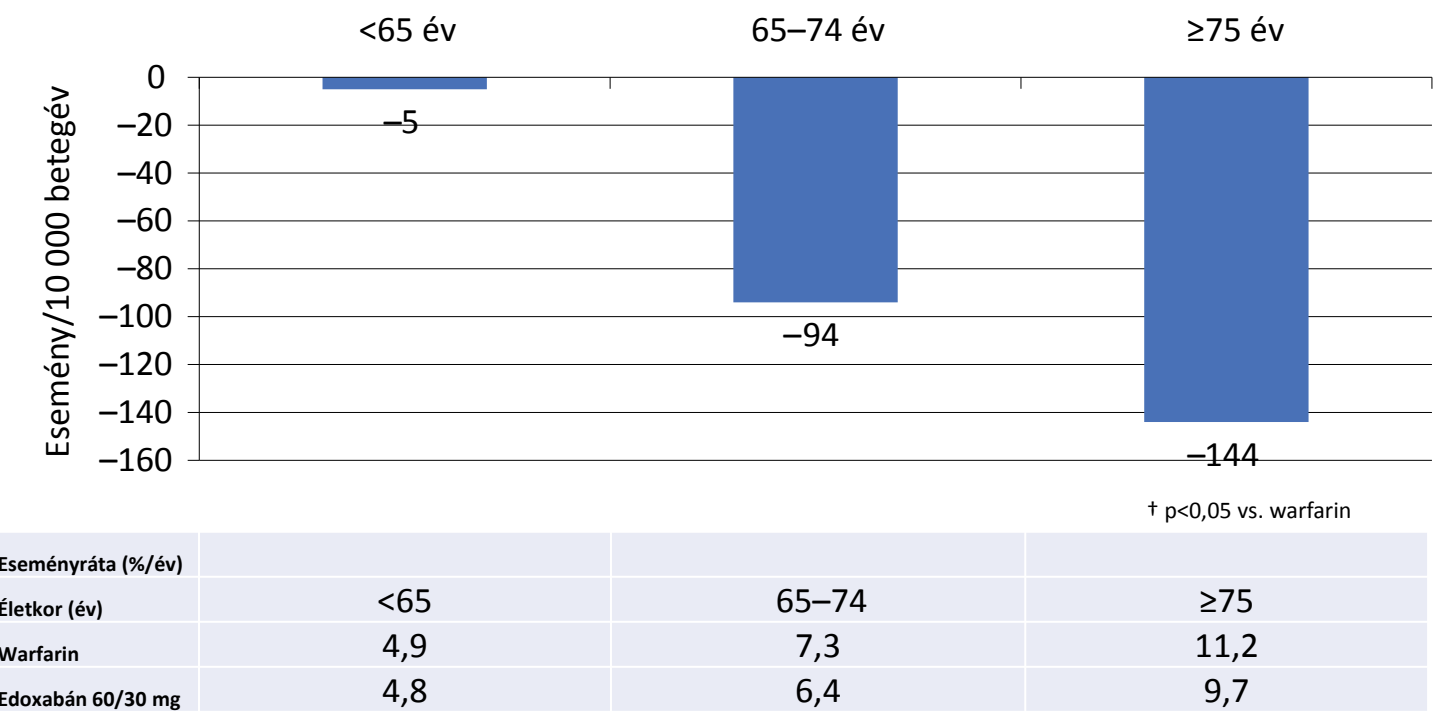

1. ábra | Az edoxabán az idősek között mutatott kifejezettebb nettó klinikai előnyt az ENGAGE AF vizsgálatban

legalább olyan jó a stroke vagy a szisztémás emboliás események megelőzése tekintetében, mint a warfarin, ugyanakkor ezt szignifikánsan kevesebb vérzéses szövődménnyel éri el [12]. Szignifikánsan kevesebb cardiovascularis halálozás is volt az edoxabánágon. A vizsgálat utólagos elemzésekor azt találták, hogy a warfarinágon tapasztalt szignifikánsan magasabb halálozás oka a gya-

2. táblázat A négy DOAC hatásának összefoglalása* stroke és szisztémás embolisatio valamint major vérzés előfordulása tekintetében a 65-74 éves és a 75 éves és annál idősebb betegek körében a klinikai vizsgálatok eredményei alapján (Turagam nyomán [14])

\begin{tabular}{lcc|cc}
\hline & $\begin{array}{c}\text { Stroke/szisztémás } \\
\text { embolia }(\% / \text { év })\end{array}$ & \multicolumn{2}{c}{$\begin{array}{c}\text { Major vérzés } \\
(\% / \text { év })\end{array}$} \\
\hline & $65-74$ év $\quad \geq 75$ év & $65-74$ év $\quad \geq 75$ év \\
\hline RE-LY & 0,9 & 1,4 & 2,1 & 5,1 \\
Dabigatrán 150 mg & 1,4 & 2,1 & 3,0 & 4,4 \\
Warfarin &
\end{tabular}

\begin{tabular}{lcccc}
\hline ROCKET-AF & & & & \\
Rivaroxabán & 2,0 & 2,3 & 2,7 & 4,9 \\
Warfarin & 2,1 & 2,9 & 2,8 & 4,4 \\
\hline ARISTOTLE & & & & \\
Apixabán & 1,2 & 1,6 & 2,0 & 3,3 \\
Warfarin & 1,7 & 2,2 & 2,8 & 5,2 \\
\hline ENGAGE AF & & & & \\
Edoxabán 60 mg & 1,7 & 1,9 & 2,5 & 4,0 \\
Warfarin & 1,8 & 2,3 & 3,3 & 4,8 \\
\hline
\end{tabular}

*Nincsenek direkt összehasonlító vizsgálatok a négy DOAC gyógyszerrel. koribb fatális vérzéses szövődmény volt. Az edoxabán egyrészt direkt módon, a kevesebb halálos vérzés előfordulása miatt, másrészt indirekt módon, a vérzéssel összefüggő kevesebb szövődmény, valamint a nem fatális vérzés kapcsán leállított terápia útján ért el kevesebb halált [15].

Az irodalom és a tapasztalatok alapján a napi egyszeri adagolású edoxabán alkalmazása biztonsággal ajánlható, mert a thromboticus események megelőzésében legalább annyira hatékony, mint a warfarin, ugyanakkor a vérzéses szövődmények ritkábbak. A betegek életkorát figyelembe vevő utólagos elemzés azt igazolja, hogy adása idősebb életkorban különösen kedvező [14].

Anyagi támogatás: A közlemény megjelenését az MSD Pharma Hungary Kft. támogatta.

A cikk végleges változatát a szerző elolvasta és jóváhagyta.

Érdekeltségek: A szerzőnek nincsenek érdekeltségei.

\section{Irodalom}

[1] Kirchhof P, Benussi S, Kotecha D, et al. 2016 ESC Guidelines for the management of atrial fibrillation developed in collaboration with EACTS. Eur Heart J. 2016; 37: 2893-2962.

[2] Chugh SS, Havmoeller R, Narayanan K, et al. Worldwide epidemiology of atrial fibrillation: a Global Burden of Disease 2010 Study. Circulation 2014; 129: 837-847.

[3] Gladstone DJ, Bui E, Fang J, et al. Potentially preventable strokes in high-risk patients with atrial fibrillation who are not adequately anticoagulated. Stroke 2009; 40: 235-240. 
[4] Márk L, Dani Gy, Nagy M, et al. The quality of oral anticoagulant therapy with vitamin $\mathrm{K}$ antagonists in atrial fibrillation. [Kvitamin-antagonistákkal történt orális antikoaguláns kezelés minősége pitvarfibrillációban szenvedő betegekben.] Cardiol Hung. 2013; 43: 233-238. [Hungarian]

[5] Mark L, Dani Gy, Vendrey R, et al. Oral anticoagulant therapy and bleeding events with vitamin $\mathrm{K}$ antagonists in patients with atrial fibrillation in a Hungarian county hospital. Med Sci Monit. 2015; $21: 518-525$.

[6] Tomcsányi J, Salfer B, Nagy B. Old and new oral anticoagulants in the management of atrial fibrillation. Hungarian data. [Régi és új orális antikoagulánsok hazai alkalmazása pitvarfibrillációban.] Orv Hetil. 2017; 158: 1545-1549. [Hungarian]

[7] Kiss RG. Direct oral anticoagulants in cardiology. [Direkt orális antikoagulánsok a kardiológiában.] Orv Hetil. 2016; 157: 1507-1510.

[8] Csanádi Z. Risk of thromboembolism in atrial fibrillation [Thromboemboliás kockázat pitvarfibrillációban.] Orv Hetil. 2016; 157: 1511-1515

[9] Ogilvie IM, Newton N, Welner SA, et al. Underuse of oral anticoagulants in atrial fibrillation: a systematic review. Am J Med. 2010; 123: 638-645.e4.

[10] Xian Y, O'Brien EC, Liang L, et al. Association of preceding antithrombotic treatment with acute ischemic stroke severity and in-hospital outcomes among patients with atrial fibrillation. JAMA 2017; 317: 1057-1067.
[11] Ruff CT, Giugliano RP, Braunwald E, et al. Association between edoxaban dose, concentration, anti-factor Xa activity, and outcomes: an analysis of data from the randomised, double-blind ENGAGE AF-TIMI 48 trial. Lancet 2015; 385: 2288-2295.

[12] Giugliano RP, Ruff CT, Braunwald E, et al. Edoxaban versus warfarin in patients with atrial fibrillation. N Engl J Med. 2013; 369: 2093-2104.

[13] Kato ET, Giugliano RP, Ruff CT, et al. Efficacy and safety of edoxaban in elderly patients with atrial fibrillation in the ENGAGE AF-TIMI 48 Trial. J Am Heart Assoc. 2016; 5: e003432.

[14] Turagam MK, Velagapudi P, Flaker GC. Stroke prevention in the elderly atrial fibrillation patient with comorbid conditions: focus on non-vitamin $\mathrm{K}$ antagonist oral anticoagulants. Clin Interv Aging 2015; 10: 1431-1444

[15] Giugliano RP, Ruff CT, Wiviott SD, et al. Mortality in patients with atrial fibrillation randomized to edoxaban or warfarin: in sights from the ENGAGE AF-TIMI 48 Trial. Am J Med. 2016; 129: 850-857.e2.

(Márk László dr., Gyula, Semmelweis u. 1., 5700 e-mail: mark@pandy.hu)

A közlemény megjelenését az MSD Pharma Hungary Kft. tette lehetővé.

Az itt közölt információk a szerző véleményét tükrözik, amely eltérhet az MSD Pharma Hungary Kft. álláspontjától. A megemlített termékek használatakor az érvényes alkalmazási eloórás az irányadó.

\section{MEGHÍV Ó}

\section{A Szent János Kórház és Észak-budai Egyesített Kórházak Tudományos Bizottsága}

a Fül-, Orr-, Gége és Szájsebészeti Osztály valamint a Neurológiai Osztály

tisztelettel meghívja az érdeklődőket a következő tudományos ülésére.

Időpont: 2018. május 31. (csütörtök) 14 óra

Helyszín: Szent János Kórház Auditóriuma - 1125 Budapest, Diós árok 1-3.

Téma: „Neuro-otológiai újdonságok és differenciáldiagnosztikai problémák”

Üléselnök: Dr. Jánosi András

\section{Program:}

Dr. Tamás T. László: (Petz Aladár Megyei Oktató Kórház, Fül-Orr-Gégészeti és Fej-,

Nyaksebészeti Osztály, Győr): Perifériás eredetű szédülés, ágy melletti differenciáldiagnosztika

15 perc

Dr. Béres-Molnár Katalin Anna (Neurológiai Osztály - Stroke Centrum): Centrális eredetü szédülés

15 perc

Dr. Folyocich András (Neurológiai Osztály): Stroke és góckérdés

15 perc

Dr. Liktor Balázs (Fül-, Orr-, Gége és Szájsebészeti Osztály): Arc- és fejájás fül-orr-gégész szemmel

15 perc

Minden érdeklődőt szeretettel várunk. 